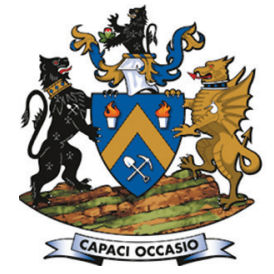

Affiliation:

${ }^{1}$ Associate Professor - School of Mining Engineering, University of the Witwatersrand,

Johannesburg.

2 Group Mineral Resources Manager - Northam Platinum. ${ }^{3}$ Principal Researcher - CSIR.

\section{Correspondence to:}

B. Watson

\section{Email:}

Bryan.Watson@wits.ac.za

\section{Dates:}

Received: 9 Mar. 2020

Revised: 21 Dec. 2020

Accepted: 18 Jan. 2021

Published: January 2021

\section{How to cite:}

Watson, B.P., Hoffmann, D., and

Roberts, D.P. 2021

Investigation of stress in potholes in the Bushveld Complex: A case study.

Journal of the Southern African Institute of Mining and Metallurgy, vol. 121, no. 1, pp. 47-56

DOI ID:

http://dx.doi.org/10.17159/24119717/1152/2021

\section{ORCID}

B.P. Watson

https://orcid.org/0000-0003-

0787-8767

D. Hoffmann

https://orcid.org/0000-00034660-2018

\title{
Investigation of stress in a pothole in the Bushveld Complex: A case study
}

\author{
B.P. Watson ${ }^{1}$, D. Hoffmann ${ }^{2}$, and D.P. Roberts ${ }^{3}$
}

\section{Synopsis}

Potholes on the Merensky and UG2 reefs in the Bushveld Complex occur as near-circular to elliptical depressions or slumps on the reef horizon, normally presenting as severe disruptions which prevent economic extraction. Within the pothole, the reef and other strata may either be attenuated, absent, or highly deformed, this being the result of the overlying hangingwall strata having slumped down. The hypotheses for pothole formation involve several mechanisms, including downward erosion, upward fluid movement, or synmagmatic deformation.

When potholes are exposed in mine workings, significant fracturing is often observed. This fracturing is particularly evident in anorthosite rock types. Stress measurements were conducted in a pothole on the Merensky Reef to determine if the fracturing was due to high stress conditions. The paper describes the measurement results and numerical modelling that was done to determine the influence of depth and mining on the stress condition at the site. The results show that high stresses do exist in at least some potholes, and that current formation theories do not adequately explain the measured stresses. In support of understanding the high local stress associated with the pothole, the study explored several rock engineering modelling processes to validate the conditions of the study site and enclosing excavations. A better understanding of the stress conditions in potholes with additional data could lead to more appropriate support design and avoidance of potential rockbursts in these structures.

\section{Keywords}

potholes, stress, fracturing, discontinuities, jointing, Merensky, UG2.

\section{Introduction}

Potholes are widely developed on the Merensky and UG2 reefs in the Bushveld Complex, typically having circular-to-elliptical shapes in plan, and surface areas ranging from $2 \%$ to as much as $35 \%$ of the reef area for shaft blocks. Usually one or several of the lithological layers are missing where material from the hangingwall strata appears to have slumped or scoured down and filled the underlying depression during or soon after formation (Figure 1). In a pothole, the reef may be developed, but often with irregular morphology and at a lower elevation. Some potholes are large enough to be mined, but generally they are left as stability pillars, and may form part of the regional support. Anorthositic rocks that are exposed in an excavation as a result of a pothole often display a significant amount of fracturing (Urcan et al., 2003). In some instances the fracturing is severe and the rock difficult to support, and falls of ground (FOGs) have occurred. This investigation was designed to determine whether the fracturing is due to high stress. A pothole at shallow depth below surface on the eastern limb of the Bushveld Complex was instrumented. This pothole bottomed out on the base of the Merensky Reef, i.e., the Merensky Reef was missing in the area of the pothole as shown by the schematic in Figure 1.

Usually the bases of potholes are U-shaped, but V-shaped potholes have also been recorded. The up-dip contacts of potholes are steeper, whereas the contacts in the down-dip sections tend to flatten out. The strata thicknesses within the potholes are often variable, but locally they may be similar to those of the undisturbed strata. On the mining horizon, stoping often stops short of the pothole edge where the transgressive hangingwall lithologies are found. At these locations, the attenuation of the reef may be accompanied by deteriorating ground conditions, often associated with increased jointing (Urcan et al., 2003).

In this paper we describe a case study of stress measurements that were performed from a raise line (approx. $1.8 \mathrm{~m} \times 1.8 \mathrm{~m}$ tunnel cut on the reef elevation and following the dip of the strata) cut through the centre of a pothole at a depth of $250 \mathrm{~m}$ below surface. The objective was to determine stress levels within the pothole. The cover stress was calculated to be $8 \mathrm{MPa}$ (virgin stress). The induced vertical field stress according to 3D elastic modelling, which included mining at the time of the investigation, was 


\section{Investigation of stress in a pothole in the Bushveld Complex: A case study}

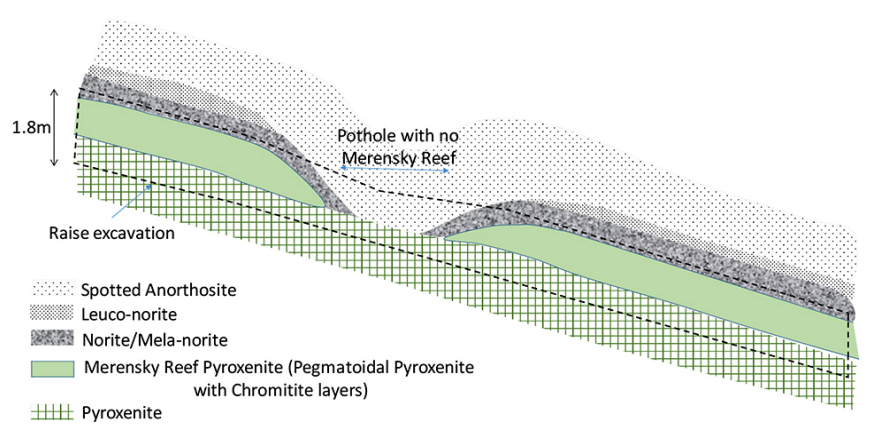

Figure 1-Schematic cross-section through the pothole and raise excavation in the study area. Note the local absence of the reef. The dashed line represents a raise tunnel

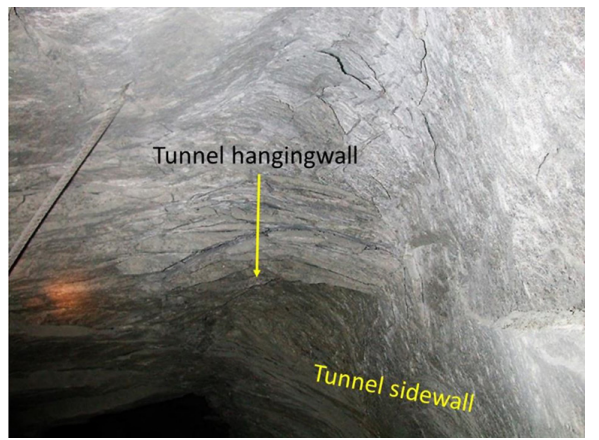

Figure 2-A view looking up the raise excavation (approx. square $1.8 \mathrm{~m} \mathrm{x}$ $1.8 \mathrm{~m}$ tunnel) on the Merensky horizon, showing stress fracturing observed in the centre of the pothole

$10 \mathrm{MPa}$. At such shallow levels, stress fracturing is not normally observed on the Merensky Reef because of the relatively high strength of the rocks. Figure 2 shows the fracturing observed at the instrumented site. The measurements described in the paper were performed as part of a PlatMine project (Watson et al., 2005). Significantly, more work has been added to the original PlatMine investigations in terms of a pothole formation theory review, baseline stress measurements, and numerical modelling. The final part of the study was to determine if current pothole formation theories could explain the measured stresses.

\section{Site description}

A site plan of the pothole is shown in Figure 3. Two distinct rock types, norite and anorthosite, were identified in the exposed section of the pothole, as shown in the figure. The stress condition was determined for each of the two rock types, and in the reef beyond the pothole from two separate boreholes. The positions and orientations of these boreholes are shown in plan and section in Figure 3 and Figure 4, respectively. The section shown in Figure 4 was estimated from borehole intersections. Figure 5 shows the collars of the boreholes in the sidewall of the approximately $1 \mathrm{~m}$ deep and $1 \mathrm{~m}$ high ledge (siding) located in the lower section of the pothole (southwest side in Figure 3). The average dip of the strata at the site was $17^{\circ}$ (outside the pothole).

A generalized stratigraphic column for the rock sequences normally surrounding the Merensky Reef, i.e., outside of a pothole area, is shown in Figure 6. In this area the Merensky Reef is typically a $1 \mathrm{~m}$ thick poikilitic feldspathic pyroxenite. The immediate hangingwall is a $0.4 \mathrm{~m}$ thick norite, overlain by a $0.4 \mathrm{~m}$ thick leuconorite which grades upwards into an approximately $3.5 \mathrm{~m}$ thick spotted anorthosite and subsequently a $7 \mathrm{~m}$ thick mottled anorthosite. No definite parting planes exist between lithologies up to the base of the Bastard Reef.

\section{Strain measurement technique}

CSIR triaxial strain cells were oriented and glued in a small diameter borehole at the desired positions for the strain measurements, and subsequently the rock surrounding the gauges was strain-relieved by overcoring with a much larger

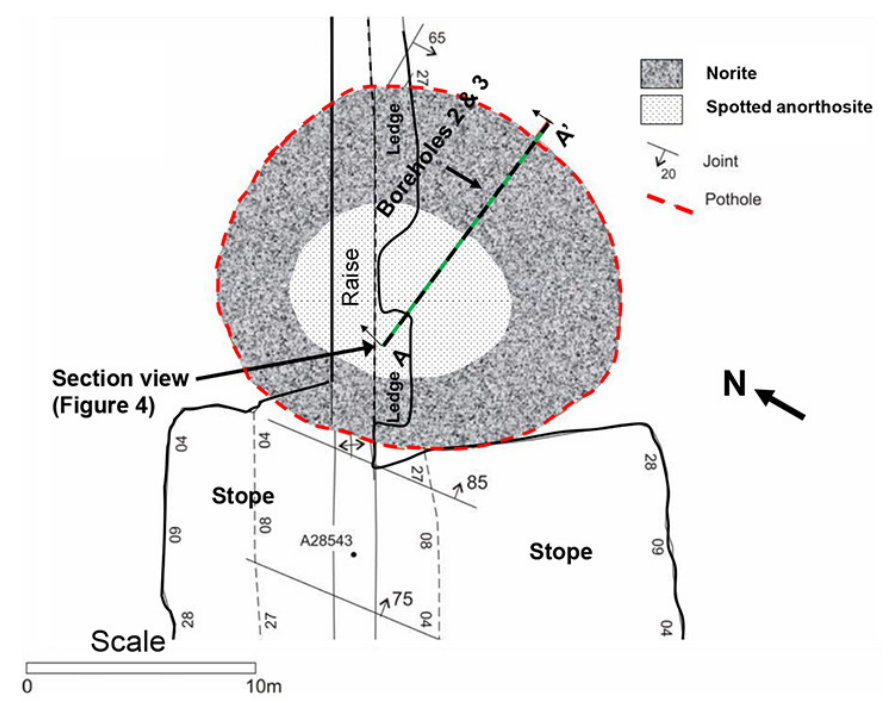

Figure 3-Plan showing the pothole in the raise and the boreholes used for the stress measurements. Note the stoped-out area below the pothole $(1 \mathrm{~m}$ stope height), and the ledge (siding), at the same height, on the right side of the centre raise in the pothole
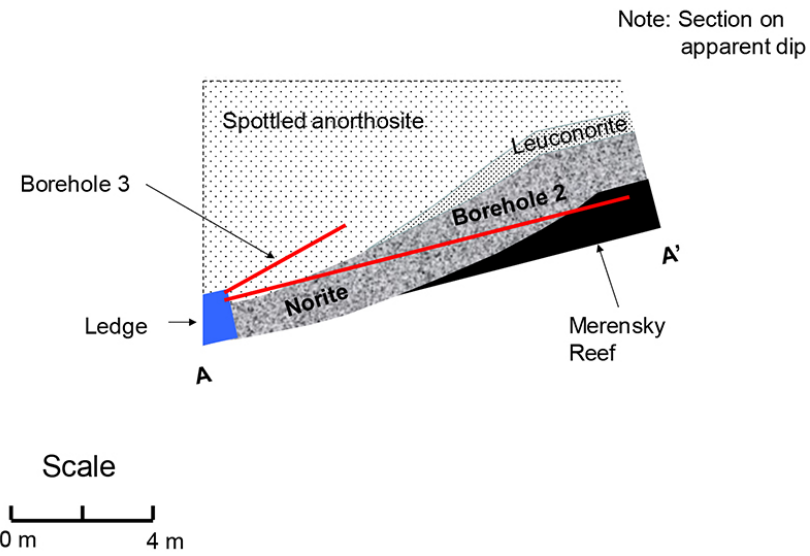

Figure 4-West-east section of the pothole through A-A' in Figure 3 (looking north) - conceptualized from observations made in the boreholes

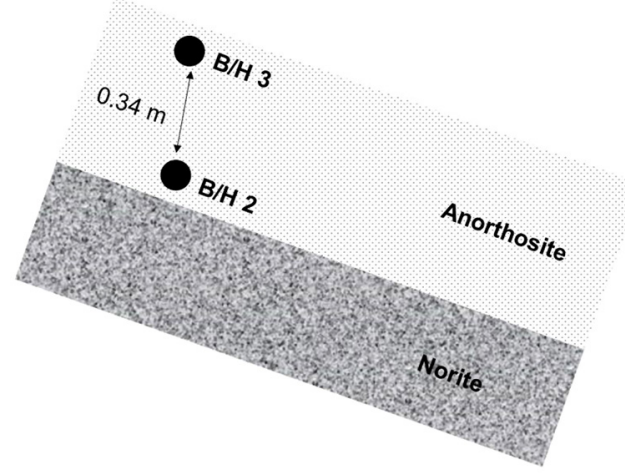

Figure 5-Front view' section, looking east as shown in Figure 3, indicating the borehole collar positions in the face of the $1 \mathrm{~m}$ deep centre-raise-ledge The $0.34 \mathrm{~m}$ gap refers to the distance between the boreholes, sidewall to sidewall 


\section{Investigation of stress in a pothole in the Bushveld Complex: A case study}

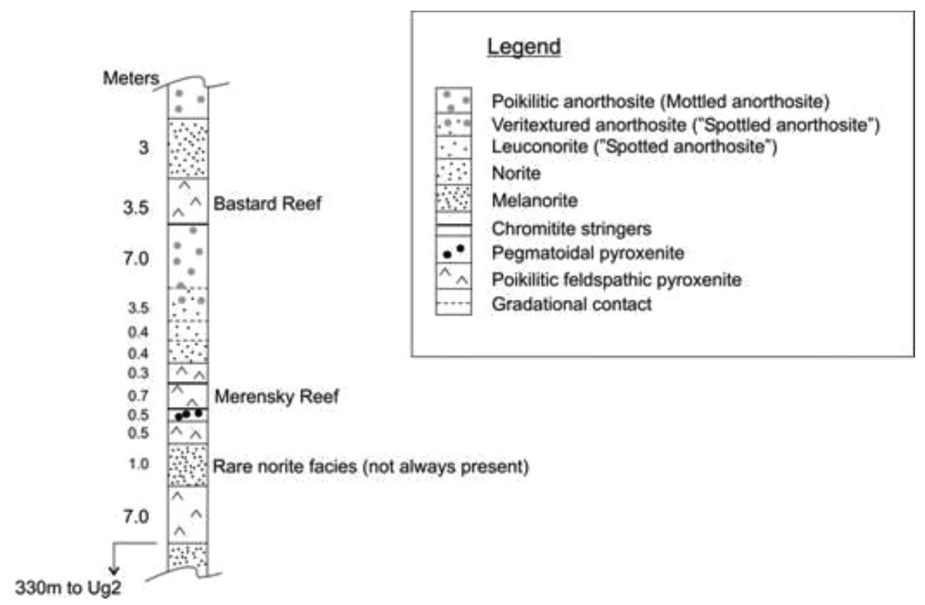

Figure 6-Generalized stratigraphic column for the normal rock sequences surrounding the Merensky Reef in the area of the measurements (represents the geology outside the pothole)

diameter bit (van Heerden, 1983). The strain gauges within the unit recorded the strain relief and the stresses were determined using standard analytical solutions (Leeman and Hayes, 1966).

\section{Stress measurement results}

The strains measured by the cells were converted to stress using the elastic constants of rock specimens that were retrieved from the same borehole, immediately adjacent to the measurement sites. Uniaxial compressive tests were performed under laboratory conditions on the two rock types. The results provided Young's moduli and Poisson's ratio values of: $67 \mathrm{GPa}$ and 0.26 , respectively, for the anorthosite; $89 \mathrm{GPa}$ and 0.18 for the norite; and $73 \mathrm{GPa}$ and 0.28 , for the pyroxenite. The stress-strain results of the tests are shown in Figure 7.

The results of the field stress measurements are provided in Table I, and shown in Figures 8 to 10. Triax 2 and triax 3 were installed in borehole 2, and triax 4 was installed in borehole 3 (Figures 8 and 9). A reliability index of less than 13 is considered acceptable (Coetzer, 2005). (The reliability index is the average percentage deviation of all the strains from the ideal strains used to calculate the stress.) Stress measurements were conducted in the anorthosite, norite, and pyroxenite, but the measurements in the norite were not considered reliable. The norite measurements were therefore not used in the analyses. The measurement in the pyroxenite was made outside, but near the edge of the pothole. The orientations of the major principal stress changed in the two rock types, from approximately WNW-ESE in the anorthosite to $\mathrm{N}-\mathrm{S}$ in the pyroxenite (Figure 8). Interestingly, the ratio between $\sigma_{1}$ and $\sigma_{3}$ in both rock types was about two.

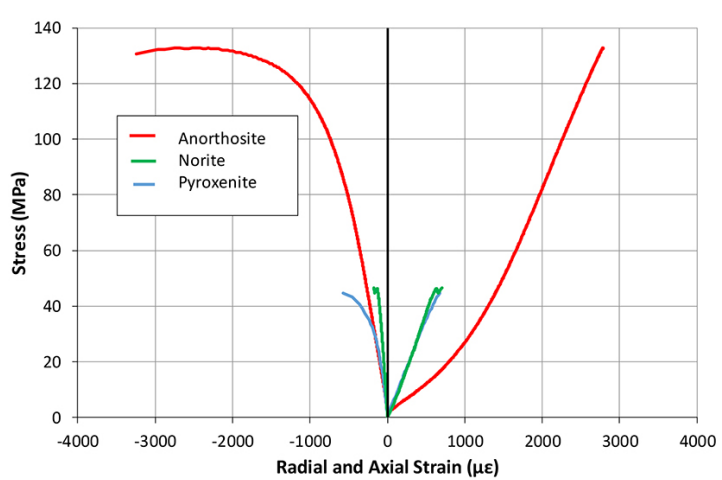

Figure 7-Uniaxial strength test results for the anorthosite, norite, and pyroxenite rock types

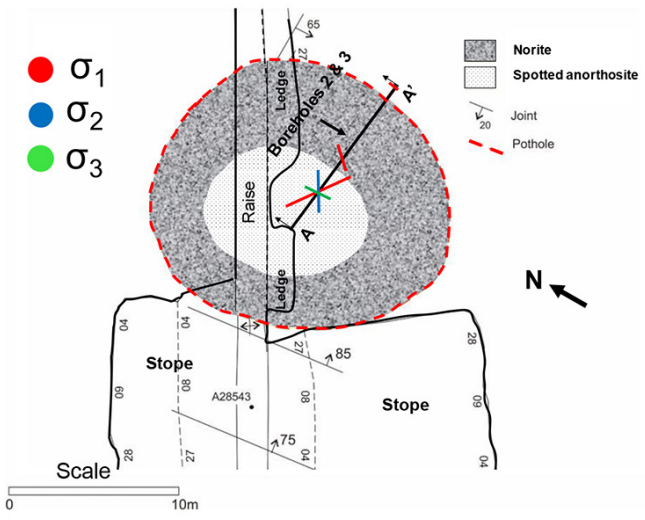

Figure 8-Plan showing the pothole and the stress measurement positions, and the orientations and magnitudes of the principal stress components

\section{Table I}

\section{Results of the stress measurements performed in a pothole $250 \mathrm{~m}$ below surface}

\begin{tabular}{|c|c|c|c|c|c|c|c|c|c|c|c|c|c|c|}
\hline $\begin{array}{l}\text { Instrument } \\
\text { no. }\end{array}$ & $\begin{array}{l}\text { Rock } \\
\text { type }\end{array}$ & $\begin{array}{c}\sigma_{1} \\
(\mathrm{MPa})\end{array}$ & $\begin{array}{l}\text { Direction } \\
\text { of } \sigma_{1} \\
\text { (deg. from } \\
\text { north) }\end{array}$ & $\begin{array}{c}\text { Dip of } \\
\sigma_{1} \text { (deg. } \\
\text { from } \\
\text { horiz.) }\end{array}$ & $\begin{array}{c}\sigma_{2} \\
(\mathrm{MPa})\end{array}$ & $\begin{array}{l}\text { Direction } \\
\text { of } \sigma_{2} \\
\text { (deg. from } \\
\text { north) }\end{array}$ & $\begin{array}{c}\text { Dip of } \\
\sigma_{2} \text { (deg. } \\
\text { from } \\
\text { horiz.) }\end{array}$ & $\begin{array}{c}\sigma_{2} \\
(\mathrm{MPa})\end{array}$ & $\begin{array}{l}\text { Direction } \\
\text { of } \sigma_{3} \\
\text { (deg. from } \\
\text { north) }\end{array}$ & $\begin{array}{c}\text { Dip of } \\
\sigma_{3} \text { (deg. } \\
\text { from } \\
\text { horiz.) }\end{array}$ & $\begin{array}{l}\text { Vert. } \\
\text { stress } \\
\text { (MPa) }\end{array}$ & $\begin{array}{c}\text { Reliability } \\
\text { index } \\
(\%)\end{array}$ & $\begin{array}{c}\text { Young's } \\
\text { modulus } \\
\text { (GPa) } \\
\text { (at } 50 \% \\
\text { of UCS) }\end{array}$ & $\begin{array}{c}\text { Poisson's } \\
\text { ratio } \\
\text { (at } 50 \% \\
\text { of } \\
\text { UCS) }\end{array}$ \\
\hline Triax 4 & $\begin{array}{l}\text { Spottled } \\
\text { anorthosite }\end{array}$ & 107 & 119 & 37 & 62 & 233 & 28 & 48 & 170 & 40 & 72 & 5.0 & 67 & 0.26 \\
\hline Triax 2 & Norite & 35 & 36 & 4 & 7 & 282 & 79 & 3 & 126 & 10 & 7 & 67.8 & 89 & 0.18 \\
\hline Triax 3 & $\begin{array}{c}\text { Pyroxenite } \\
\text { (Merensky Reef) }\end{array}$ & 16 & 180 & 37 & 11 & 286 & 19 & 8 & 37 & 47 & 11 & 8.3 & 73 & 0.28 \\
\hline
\end{tabular}




\section{Investigation of stress in a pothole in the Bushveld Complex: A case study}

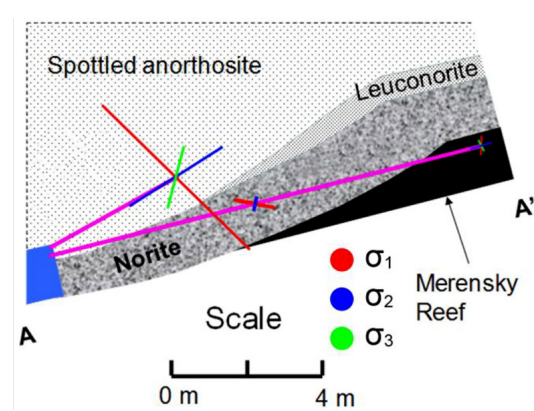

Figure 9-West-east section of the pothole through A-A' in Figure 8 (looking north) showing the stress measurement positions, and orientations and magnitudes of the principal stress components

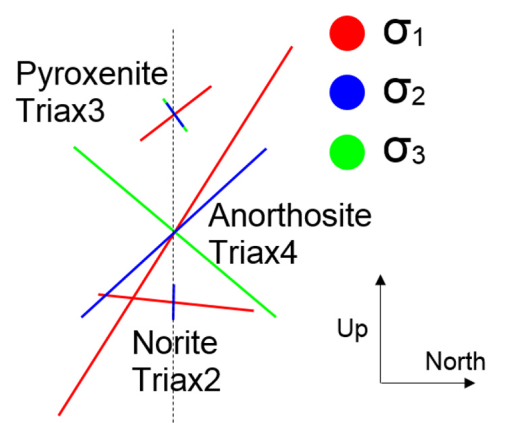

Figure 10-North-south section looking west, showing the orientations and magnitudes of the principal stress components

\section{Stresses in anorthosite elsewhere on the mine}

Coetzer (1999) conducted virgin stress measurements at the same mine, but in anorthosites that were located outside of potholes and a stratigraphic unit below the Merensky Reef. One measurement, was made at a similar depth below surface to the study site pothole, and about $500 \mathrm{~m}$ from the site horizontally. The results showed a near-horizontal major principal stress of $14 \mathrm{MPa}$ and a vertical stress of $7 \mathrm{MPa}$, which was close to the cover load (Table II). Other measurements in the same anorthosite layer, but at a depth of $470 \mathrm{~m}$ below surface (220 m deeper than the study site), showed a near-horizontal average major principal stress of $30 \mathrm{MPa}$. For most of these measurements, the vertical stress component was equivalent to the cover load (assuming a density of $3000 \mathrm{~kg} / \mathrm{m}^{3}$ ). In addition, the average k-ratio (horizontal to vertical stress) was about 1.9.

A comparison between Coetzer's (1999) stress results and those measured in the pothole suggests that the stresses in the pothole anorthosite were abnormally high (Table III). Importantly, the Coetzer (1999) measurements were conducted in virgin stress conditions, i.e., there being no mining influences on the stress state. This was not the case in the pothole measurements and therefore it was necessary to do some modelling to determine the stress state expected at the elevation of the pothole due to the cover load and surrounding mining. Since the depth below surface was shallow and the mining spans around the pothole were relatively small, it was appropriate to use an elastic model.

\section{Elastic boundary element model}

A pseudo-3D, linear elastic, boundary element code, named MinSim (COMRO, 1981) was used to estimate the field stresses expected in the pothole as a result of depth below surface and the surrounding mining. The model included a sufficient area of mining around the site to reliably determine its influence on the pothole. The stress measurements done by Coetzer (1999) had a horizontal stress/vertical stress ( $\mathrm{k}$-ratio) variation of between 1.4 and 2.4. In addition, the vertical component of stress in these measurements generally showed a stress similar to the cover load if the average density of the overlying rock was assumed to be $3000 \mathrm{~kg} / \mathrm{m}^{3}$. Ryder, Watson, and Kataka (2005) also found that elastic models provided reasonable results if the density of the rock and virgin k-ratio of $3000 \mathrm{~kg} / \mathrm{m}^{3}$ and 2, respectively, were assumed as input parameters. The model assumed uniform material throughout, and was used to determine the field stresses resulting from the mining geometry (the pothole was assumed to have the same elastic properties as the surrounding rock mass for the purposes of this analysis). Stresses were calculated at even intervals along a line representing borehole 2 . The model results are shown together with the stress measurements in Figure 11.

Table II

Results of the stress measurements performed outside a pothole $297 \mathrm{~m}$ below surface

\begin{tabular}{|c|c|c|c|c|c|c|c|c|c|c|c|c|c|c|}
\hline $\begin{array}{l}\text { Instrument } \\
\text { no. }\end{array}$ & $\begin{array}{l}\text { Rock } \\
\text { type }\end{array}$ & $\begin{array}{c}\sigma_{1} \\
(\mathrm{MPa})\end{array}$ & $\begin{array}{l}\text { Direction } \\
\text { of } \sigma_{1} \\
\text { (deg. from } \\
\text { north) }\end{array}$ & $\begin{array}{l}\text { Dip of } \\
\sigma_{1} \text { (deg. } \\
\text { from } \\
\text { horiz.) }\end{array}$ & $\begin{array}{c}\sigma_{2} \\
(\mathrm{MPa})\end{array}$ & $\begin{array}{l}\text { Direction } \\
\text { of } \sigma_{2} \\
\text { (deg. from } \\
\text { north) }\end{array}$ & $\begin{array}{c}\text { Dip of } \\
\sigma_{2} \text { (deg. } \\
\text { from } \\
\text { horiz.) }\end{array}$ & $\begin{array}{c}\sigma_{2} \\
(\mathrm{MPa})\end{array}$ & $\begin{array}{l}\text { Direction } \\
\text { of } \sigma_{3} \\
\text { (deg. from } \\
\text { north) }\end{array}$ & $\begin{array}{c}\text { Dip of } \\
\sigma_{3} \text { (deg. } \\
\text { from } \\
\text { horiz.) }\end{array}$ & $\begin{array}{c}\text { Vert. } \\
\text { stress } \\
\text { (MPa) }\end{array}$ & $\begin{array}{c}\text { Reliability } \\
\text { index } \\
(\%)\end{array}$ & $\begin{array}{c}\text { Young's } \\
\text { modulus } \\
\text { (GPa) } \\
\text { (at } 50 \% \\
\text { of UCS) }\end{array}$ & $\begin{array}{l}\text { Poisson's } \\
\text { ratio } \\
\text { (at } 50 \% \\
\text { of } \\
\text { UCS) }\end{array}$ \\
\hline B6-3 & $\begin{array}{c}\text { Spottled } \\
\text { anorfhosite }\end{array}$ & 14.1 & 26.4 & 16.0 & 10.1 & 282.6 & 39.6 & 4.0 & 133.6 & 46.0 & 7.3 & 6.7 & 76 & 0.2 \\
\hline
\end{tabular}

\section{Table III}

Results of the stress measurements performed in a pothole $250 \mathrm{~m}$ below surface

\begin{tabular}{|c|c|c|c|c|c|c|c|c|c|c|c|c|c|c|}
\hline $\begin{array}{l}\text { Instrument } \\
\text { no. }\end{array}$ & $\begin{array}{l}\text { Rock } \\
\text { type }\end{array}$ & $\begin{array}{c}\sigma_{1} \\
(\mathrm{MPa})\end{array}$ & $\begin{array}{l}\text { Direction } \\
\text { of } \sigma_{1} \\
\text { (deg. from } \\
\text { north) }\end{array}$ & $\begin{array}{c}\text { Dip of } \\
\sigma_{1} \text { (Ddeg. } \\
\text { from } \\
\text { horiz.) }\end{array}$ & $\begin{array}{c}\sigma_{2} \\
(\mathrm{MPa})\end{array}$ & $\begin{array}{l}\text { Direction } \\
\text { of } \sigma_{2} \\
\text { (deg. from } \\
\text { north) }\end{array}$ & $\begin{array}{c}\text { Dip of } \\
\sigma_{2} \text { (deg. } \\
\text { from } \\
\text { horiz.) }\end{array}$ & $\begin{array}{c}\sigma_{2} \\
(\mathrm{MPa})\end{array}$ & $\begin{array}{l}\text { Direction } \\
\text { of } \sigma_{3} \\
\text { (deg. from } \\
\text { north) }\end{array}$ & $\begin{array}{c}\text { Dip of } \\
\sigma_{3} \text { (deg. } \\
\text { from } \\
\text { horiz.) }\end{array}$ & $\begin{array}{l}\text { Vert. } \\
\text { stress } \\
\text { (MPa) }\end{array}$ & $\begin{array}{c}\text { Reliability } \\
\text { index } \\
(\%)\end{array}$ & $\begin{array}{c}\text { Young's } \\
\text { modulus } \\
\text { (GPa) } \\
\text { (at } 50 \% \\
\text { of UCS) }\end{array}$ & $\begin{array}{c}\text { Poisson's } \\
\text { ratio } \\
\text { (at } 50 \% \\
\text { of } \\
\text { UCS) }\end{array}$ \\
\hline Triax 4 & $\begin{array}{c}\text { Spottled } \\
\text { anorfhosite }\end{array}$ & 107 & 119 & 37 & 62 & 233 & 28 & 48 & 170 & 40 & 72 & 5.0 & 67 & 0.26 \\
\hline
\end{tabular}




\section{Investigation of stress in a pothole in the Bushveld Complex: A case study}

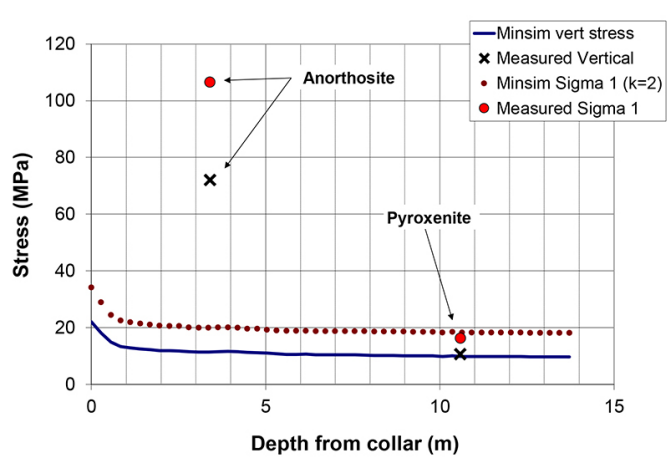

Figure 11-Major principal- and vertical- stress measurements compared to elastic results calculated by MinSim

The magnitudes of both the major principal and vertical stresses measured in the pyroxenite lithology were similar to the elastic model. These results suggest that the stresses outside of the pothole (near the edge of the pothole) were not disturbed by the pothole, and furthermore, were aligned with the range of k-ratios measured by Coetzer (1999). The vertical stress component in the pothole anorthosite, however, was significantly larger at $72 \mathrm{MPa}$.

Verification of the model was done using a similar elastic model (MAP3D, 2013) with the same input parameters, and was found to provide similar results (Figure 12). Importantly, the stress profiles along boreholes 2 and 3 in Figure 12, were shown to be similar in the region where the measurements were made.

\section{Analysis of stress measurements}

A back-analysis of the stress results was done to determine the influence of mining on the measured stress. MAP3D (2013) was used for this analysis because MinSim was not available to the authors at the time this work was done. The assumptions were that the k-ratio was maintained, and the cover load in the model was increased until the principal stress profiles at the study site coincided with the measured stresses in the spotted anorthosite. The depth of cover required to produce the measured principal stresses was about $1400 \mathrm{~m}$, which provided virgin principal stresses of $41 \mathrm{MPa}$ and $82 \mathrm{MPa}$ in the vertical and horizontal directions, respectively. Figure 13 shows the influence of mining on the virgin stress magnitudes at the positions of the measured stresses in the anorthosite. Importantly, the orientations of the field principal stresses in the model are not the same as those that were measured. The modelling implies that the mining influenced the dip of the major principal stress by only $4^{\circ}$ from horizontal. The measurements revealed that the dip was about $37^{\circ}$ (Table I). Examine2D (Curran and Corkum, 1988), which is a $2 \mathrm{D}$ elastic model, was used to determine the possible influence of the surrounding excavations if the orientation of the major principal stress was at $37^{\circ}$ (Figure 14). The results show that the magnitude of the stresses could have been influenced by a further $6 \%$ (Figure 15), i.e. the virgin major principal stress in the pothole would have been about $77 \mathrm{MPa}$.

It could be argued that the dissimilar moduli of the material in the pothole may have affected the stress, i.e. a zone with a different modulus would have been affected differently by the mining. However, the modulus of the anorthosite was lower than the values for both the surrounding norite and pyroxenite

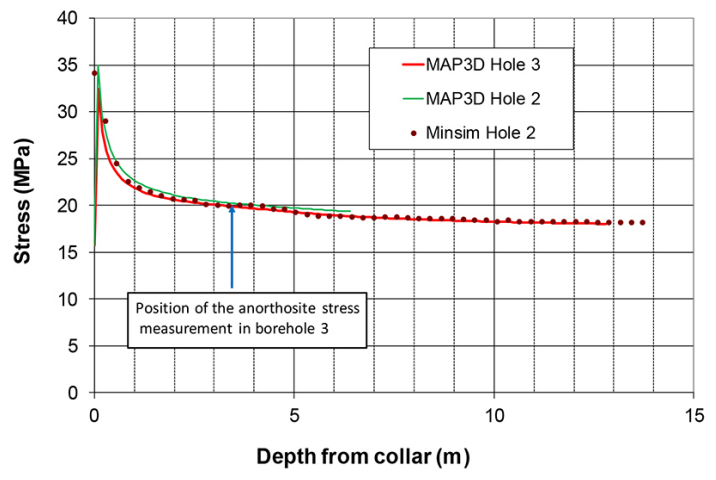

Figure 12-MAP3D/MinSim comparison for boreholes 2 and 3

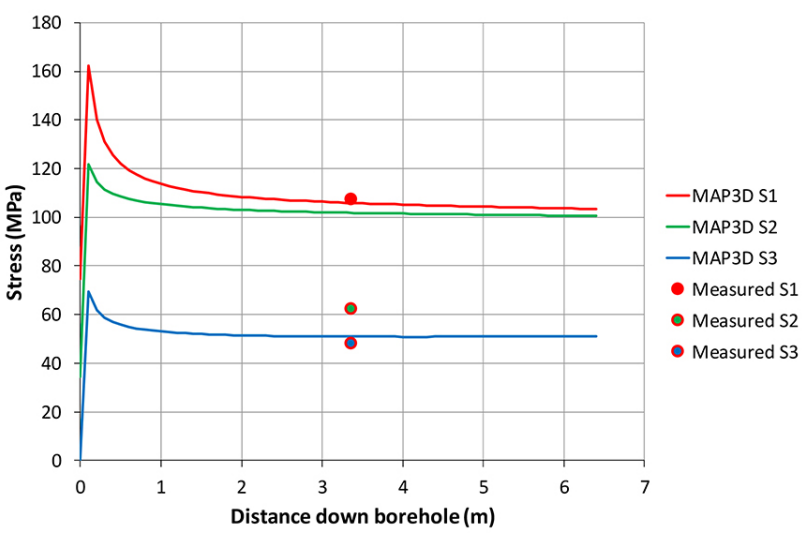

Figure 13-Stress profile with an increased cover load to coincide with the measured major principal stress in the anorthosite. S1, S2, and S3 refer to the principal stresses

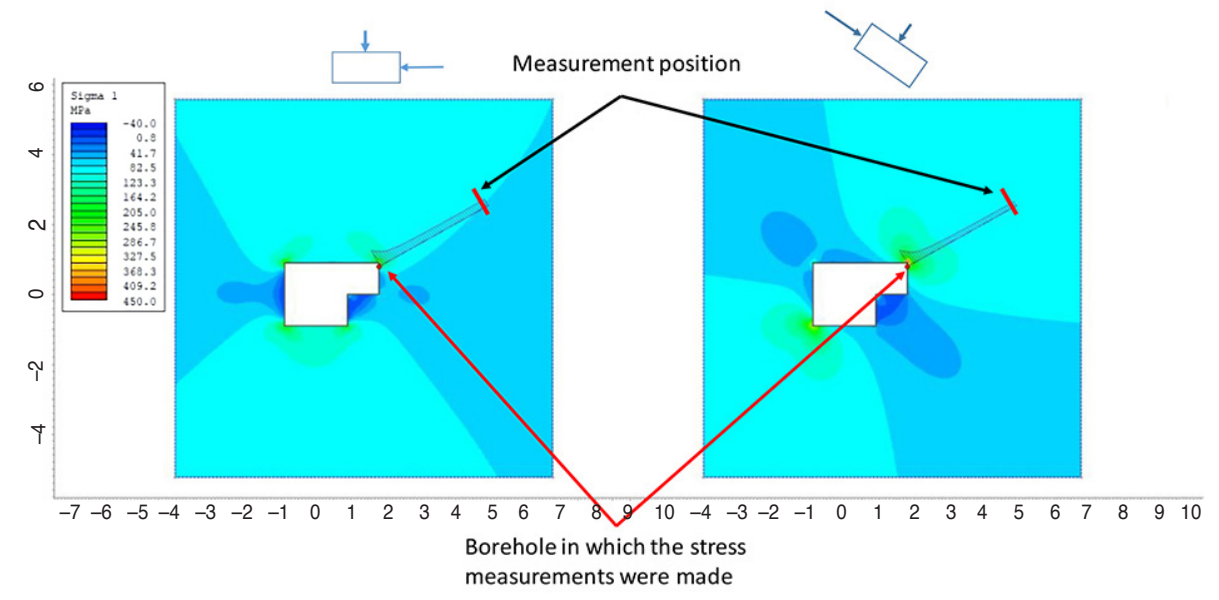

Figure 14-Influence of stress orientation on the stress measurements, Sigma 1 horizontal (left) and $37^{\circ}$ (right) 


\section{Investigation of stress in a pothole in the Bushveld Complex: A case study}

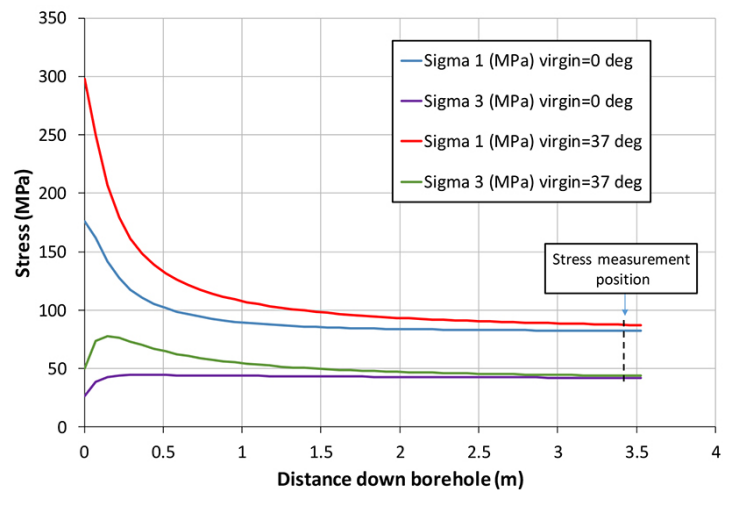

Figure 15-Results of the Examine2D modelling. The influence of the stress orientation is shown by the difference in the zero and $37^{\circ}$ lines

and therefore should have had the opposite effect (i.e. lower stresses would be expected in the lower modulus anorthosite). The FLAC3D (Itasca Consulting Group, Inc., 2017) modelling, described below, suggests that the difference in measured modulus had a minimal effect.

\section{Visual evidence of high stress in the pothole}

Confirmation of the stress and its orientations was evident in the field observations made in the raise. On the southwest side of the pothole, a blast-hole socket was observed near the collar of the boreholes used for the stress measurements. This socket was left during the original mining of the raise, and was therefore not influenced by subsequent stoping. Blast-hole sockets can be used to estimate stress ratios (Watson et al., 2006). Blast gases follow the line of least resistance, and in the absence of jointrelated influences will force the rock to open parallel to the minor principal stress. Sockets will thus elongate in the direction of the major principal stress, and the ratio of largest and smallest dimensions of the oval shape will be similar to the ratio of the major to minor principal stresses. The socket in Figure 16 showed a stress ratio of about 2:1, and suggested a near-horizontal direction of the major principal stress in the plane of the raise.

Gothic arching or dog-earing (borehole breakout) occurs when tunnels or boreholes are created/drilled in high stress conditions (Jager and Ryder, 1999). The orientation of the major principal stress will, in this instance, be perpendicular to the elongation, and the severity of the condition is dependent on the magnitude of the principal stresses in the plane of the tunnel or borehole (Jager and Ryder, 1999). Gothic arching can be clearly observed in Figure 17, again suggesting a near-horizontal major principal stress direction in the plane of the raise. The photograph was taken in the centre of the pothole, looking updip, i.e., towards the northeast. The orientation of the breakout correlates with that of the measurements, and the severity once more suggests high stress conditions. Figure 18 shows extensive fracturing that was observed in the raise hangingwall, in the anorthosite around the centre of the pothole. The authors have observed such intense fracturing elsewhere in high stress environments, particularly in anorthositic and quartzitic rock types.

Towards the top and bottom of the pothole in the norite rock type, the intensity of the fracturing reduced. In addition, evidence at the upper (northeast) side of the pothole suggested that the orientation of the breakout, and thus the principal stresses, may have changed in the norite (Figure 19).

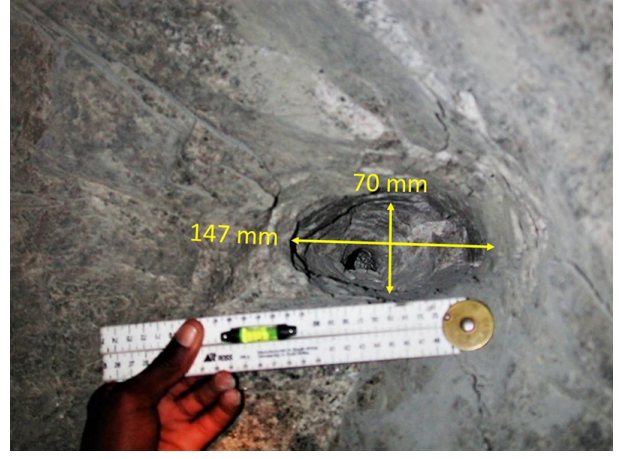

Figure 16-Blast-hole socket in the ledge at the stress measurement site

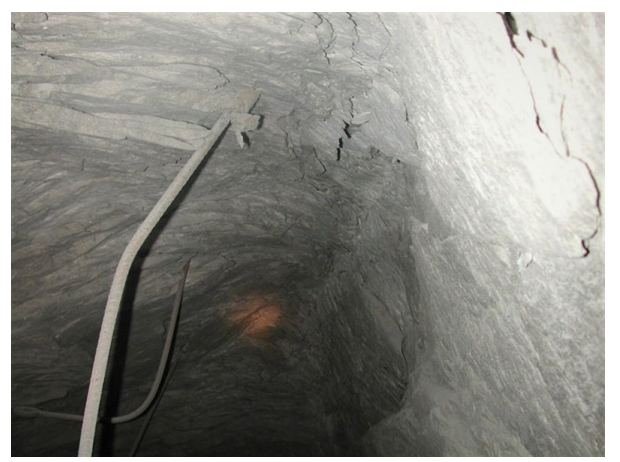

Figure 17-Looking northeast up the raise in the centre of the pothole

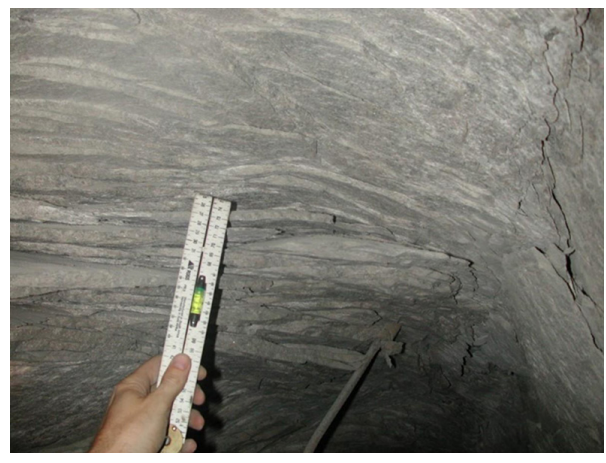

Figure 18-Extensive fracturing in the anorthosite, in the hangingwall of the raise

The orientation of the breakout in the raise tunnel, where it was located in the anorthosite, suggested a near-horizontal major principal stress, dipping towards the southeast, which was similar to the orientation of the measured principal stresses in the same rock type. The blast-hole socket dimensions implied a ratio between the major and minor principal stresses of about $2: 1$, in the plane of the raise tunnel, which was also similar to the measured stress in the anorthosite. The intensity of the fracturing agrees with the high stresses measured in the anorthosite. Although the stress measurements made in the norite are not considered reliable, there does appear to be some agreement between the observations and the measurements regarding a much lower magnitude of stress in the norite compared to stress in the anorthosite.

\section{Laboratory rock tests}

Geomechanical tests were conducted on the two rock types in the pothole and the Merensky Reef pyroxenite taken near the edge of the pothole (Figure 7). All the materials were weaker than elsewhere on the mine, as shown in Table IV. 


\section{Investigation of stress in a pothole in the Bushveld Complex: A case study}

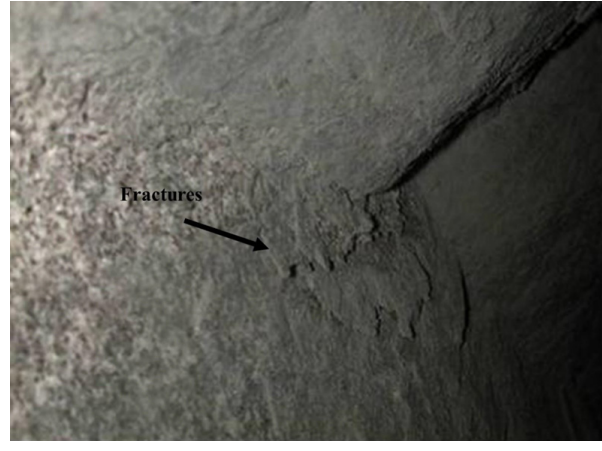

Figure 19-Fracturing in the sidewall looking northeast up the raise

The geomechanical behaviour of the anorthosite sample was compared to a more typical sample of the same rock type elsewhere on the mine (Figure 20). The significant nonlinear behaviour shown by the sample from the pothole is typical of a deeper mine with high virgin stress conditions, or a borehole being drilled into relatively high stress conditions. Similar conditions were recorded by Watson et al. (2009) in areas of high stress on other Bushveld platinum mines. The nonlinear behaviour is caused by micro-cracks that develop between different minerals in a polycrystalline material during unloading. The micro-cracks would also explain the relative weakness of the rocks in the pothole.

\section{Pothole formation theory}

Key to the formation of potholes is an earlier defect in the cumulate pile (underlying crystallized material) that led to development of the cavity. Earlier research, summarized by Ballhaus (1988) reveals a variety of processes that have been interpreted to serve as a mechanism for pothole formation. These include scouring of the cumulate pile by magmatic currents, resorption (re-melting of the cumulate pile) to form cavities related to the influx of new superheated magma, and suppressed development of the cumulate pile due to volatiles from localized fumaroles in the footwall, or subsequent collapse of the underlying cumulate pile due to localized overpressure from the volatiles. These synmagmatic mechanisms are plausible explanations for the development of the cavities, which were subsequently filled by replenishing magma. An alternative and generally preferred model is the 'pull-apart' mechanism of Carr Groves, and Cawthorne (1994) where tensional conditions in the underlying cumulate pile promote separation (pull-apart) within the footwall due to the effect of 'cumulate sagging and layerparallel slip', a result from loading by the replenishing magma. These sites of extension promote the development of cavities, and were likely the preferred sites for later magmatic erosion or devolatilization processes.

In this study, the high compressive stress values measured in the hangingwall strata are notably higher within the pothole footprint, and also higher than that predicted from the numerical modelling. According to the model of Carr, Groves, and Cawthorne (1994), an extensional environment together with its lower stress regime along the perimeter of the Bushveld Complex would be associated with the formation of cavities. However, this theory does not support the higher measured stress for the pothole in the study area. A higher compressive stress environment would be located towards the deeper central part of the Bushveld Complex where the effect of the depositional loading would be

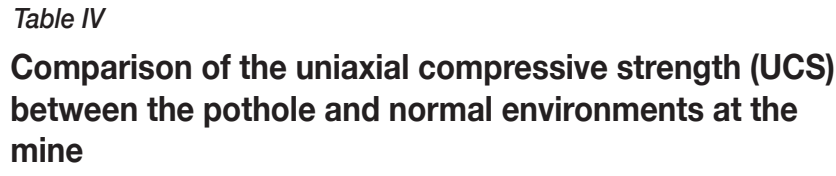

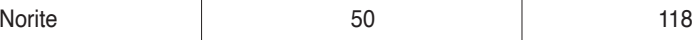

\begin{tabular}{l|r|r} 
Pyroxenite & 45 & 100
\end{tabular}

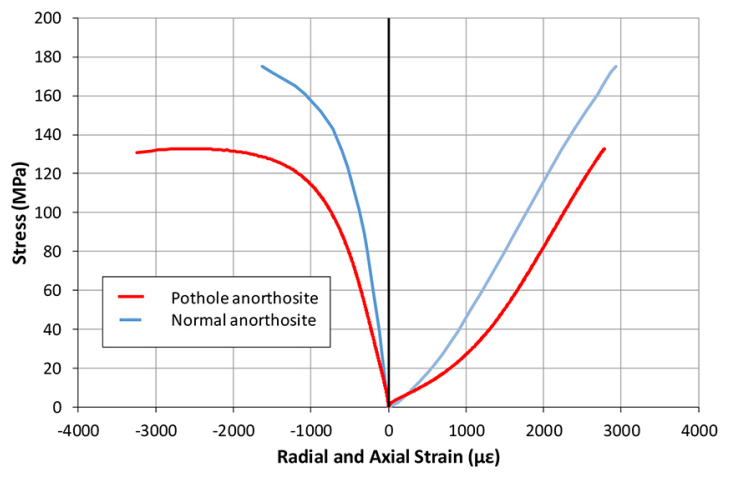

Figure 20-Comparison between the geomechanical behaviour of the pothole anorthosite and the same rock type elsewhere on the same mine

the greatest. The instrumented site is proximal to the edge of the present erosional limit, being about $800 \mathrm{~m}$ from the suboutcrop position.

\section{Possible explanation for the high stress condition in the pothole}

While none of the explored theories of magmatic processes for pothole formation adequately explain the measured stress, the higher compressive stress measured in the spotted anorthosite may be related to the behaviour of the strata in response to destressing from erosion of the land surface. This may have been aided by the concentration of stress in local nodes related to defects associated with the irregular geometry of the strata in the proximity of potholes.

It appears that the Bushveld magma was injected as a large sill approximately $3 \mathrm{~km}$ to $7 \mathrm{~km}$ below surface (Watson, 2004), constrained by the underlying sediments of the Transvaal Supergroup and an overlying shell of the Rooiberg lavas (Kruger, 2005). The extent of the magma intrusion was wide and shallow, exhibiting a lobate shape, interconnected between east and west and having upturned margins (Kruger, 2005) analogous to a 'flat-bottom soup dish'. The molten rock would have been subjected to a hydrostatic stress of between $80 \mathrm{MPa}$ and 190 $\mathrm{MPa}$ in its fluid state, because of its depth below surface. Once solidified, the horizontal stress in the rock mass would have been controlled by the Poisson effect when subjected to further loading and unloading. Consequently, significant horizontal stress could have been locked in when geological erosional processes brought the rock to the current depth below surface. The concept is illustrated by use of Equation [1] to determine the horizontal stress drop due to erosional process, shown in Figure 21. The Poisson's ratio for the materials appears to be similar at 0.3 (Sellers, Coetzwe, and Kamstra, 2002).

$$
q_{h}=\frac{v}{(1-v)} q_{v}
$$




\section{Investigation of stress in a pothole in the Bushveld Complex: A case study}

where

$q_{h}=$ horizontal stress

$q_{v}=$ vertical stress,

$v=$ Poisson's ratio (assumed to be 0.3) (Sellers, Coetzer, and Kamstra, 2002).

Figure 21 suggests that for the erosional theory to be the sole reason for the high stresses measured in the pothole, solidification of the rock would need to have taken place at a depth of $6.2 \mathrm{~km}$ below surface. However, the theory does not explain why such stress levels were locked into the pothole, rather than being pervasive throughout the orebody. It should be noted that Equation [1] assumes the rock mass is elastic and therefore does not account for other geological processes, such as creep, faulting, etc. An elastic model was set up using the elastic moduli of the anorthosite and surrounding norite and pyroxenite to determine whether a rock enclosed on all sides by materials with different Young's moduli could cause stress to be locked into a pothole.

\section{Elastic continuum model}

An elastic continuum (FLAC3D) model (Itasca Consulting Group, Inc., 2017) of the pothole was generated to explore possible origins of the high stresses recorded in the anorthosite, as described above. The configurations described in Figures 3 and 4 were used to generate the geometry of the pothole. The leuconorite layer was not included in the model geometry. No interfaces were specified between the strata. Figure 22 shows the strata boundaries. The model itself is provided in Figure 23. All boundaries were constrained by rollers.

Initial stresses corresponding to $4000 \mathrm{~m}$ of cover were applied. If it is assumed that the rock mass was molten at that time, the stress state would be hydrostatic. The vertical stress was then reduced by moving the uppermost boundary of the model upwards. This simulates removal of the cover load through erosion. It was expected that the lateral stresses would be proportionately reduced in accordance with the 'Poisson effect'. The stress field would be further modified by the geometry of the pothole and the different stiffness of each stratum.

An initial hydrostatic stress of $120 \mathrm{MPa}$ was applied throughout the model. The resulting $\sigma_{1}$ distribution after boundary displacement of $60 \mathrm{~m}$ is shown in Figure 24. The range of values is only $11 \mathrm{MPa}$, though it is evident that the stress in the stiffer norite layer is higher than in the surrounding strata. The lowest stresses are indicated below the centre of the pothole. The minor principal stress distribution shows the same trend. Stresses at the measurement positions are provided in Table V. The results do not correspond with the measured values. The orientations of the pyroxenite and norite measurements are not significantly altered, while the anorthosite major principal stress is rotated towards the normal of the surface defining the norite stratum within the pothole.

The model did not replicate the measured stresses, indicating that the origin and evolution of the measured stresses are more complex than the mechanism suggested in the previous section. High stresses could have been induced during the formation of the pothole, but the presence of such high stresses now, in concert with relatively low stresses around the pothole, suggests that some other mechanism (fracturing, slip along discontinuities, etc.) has 'trapped' these high stresses in a region above the pothole.

\section{Discussion of the stress results}

As far as the authors are aware, the stresses described in this

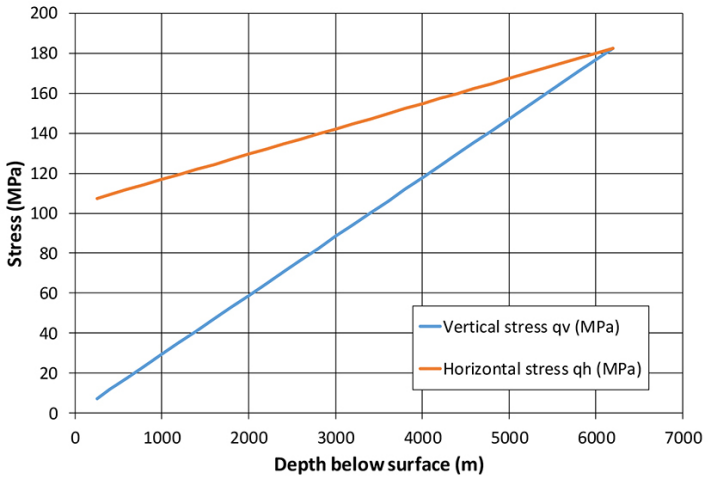

Figure 21-Change in vertical and horizontal stress with erosional processes

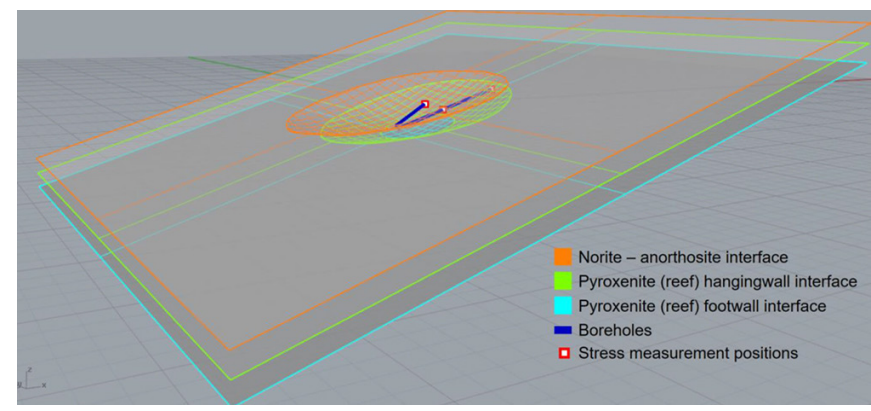

Figure 22-Interfaces used to define a continuum model of the pothole

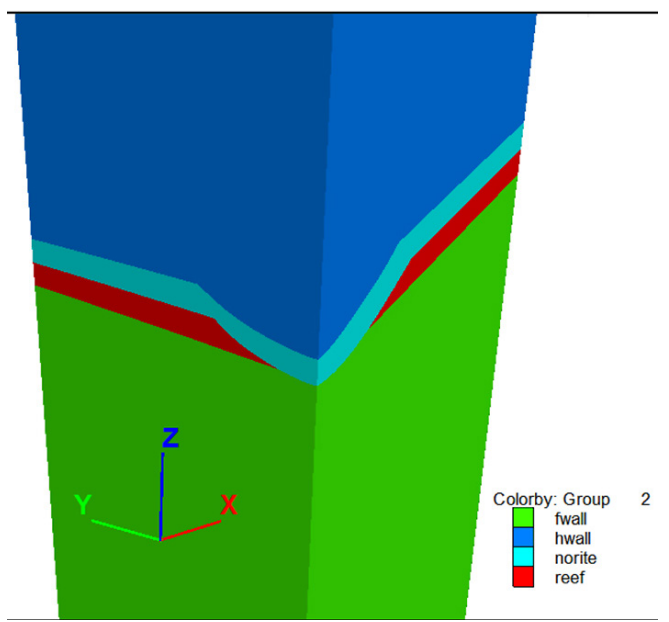

Figure 23-Model of the pothole, cut by vertical planes through the centre of the pothole

paper are the only such measurements that have been made in a pothole of the Bushveld Complex. The extensive fracturing often observed in potholes suggests that high stresses may be a common feature of potholes. Should the stress levels in some potholes increase with depth below surface, there is a possibility that bursting may occur when such features are uncovered in deeper mines. The current pothole formation theories do not adequately describe the high stress conditions that were measured or observed and therefore cannot be used to predict how potholes will behave at depth. The extensive fracturing, as shown in Figure 18, constitutes a rockfall safety hazard which is difficult to support and may also interrupt mine production.

\section{Conclusions and recommendations}

Stress fracturing is often observed in areas on the Merensky Reef 


\section{Investigation of stress in a pothole in the Bushveld Complex: A case study}

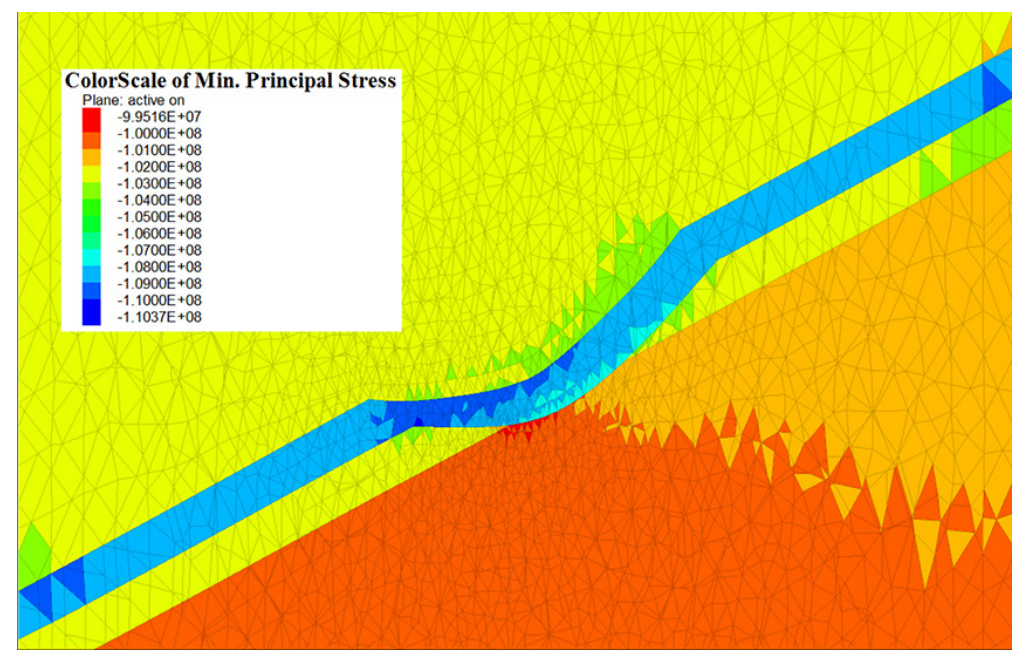

Figure 24-Modelled $\sigma_{1}$ distribution in a vertical section corresponding with the plane of the measurement boreholes

Table V

\section{Modelled principal stress vectors at the measurement positions}

\begin{tabular}{|c|c|c|c|c|c|c|c|c|c|}
\hline Measurement & $\sigma_{1}$ & $\sigma_{2}$ & $\sigma_{3}$ & Bearing 1 & Bearing 2 & Bearing 3 & Dip 1 & Dip 2 & Dip 3 \\
\hline $\begin{array}{l}\text { Norite (Triax2) } \\
\text { Pyroxenite (Triax3) } \\
\text { Anorthosite (Triax4) }\end{array}$ & $\begin{array}{l}108.4 \\
102.8 \\
103.0\end{array}$ & $\begin{array}{l}105.1 \\
102.4 \\
102.8\end{array}$ & $\begin{array}{l}71.3 \\
69.9 \\
70.3\end{array}$ & $\begin{array}{c}0.3 \\
86.2 \\
64.1\end{array}$ & $\begin{array}{l}90.3 \\
-3.8 \\
-25.9\end{array}$ & $\begin{array}{c}91.2 \\
-94.3 \\
-91.7\end{array}$ & $\begin{array}{c}0.1 \\
-0.8 \\
-1.2\end{array}$ & $\begin{array}{c}-3.4 \\
0.0 \\
0.6\end{array}$ & $\begin{array}{l}86.6 \\
-89.2 \\
-88.7\end{array}$ \\
\hline
\end{tabular}

where potholes have been exposed during mining, particularly in anorthosite rocks. Stress measurements conducted in a pothole on the Merensky Reef showed that the stresses were unusually high, yet with a similar $\sigma_{1}$ to $\sigma_{3}$ ratio to the Merensky pyroxenite outside the pothole. In addition, none of the measurements conducted in anorthosite outside of a pothole showed such high stresses. Observations of fracturing and blast-hole sockets near the high stress measurement confirmed that high stresses were present in that area.

None of the explored theories of pothole formation adequately explain the measured stress. Modelling indicated that the difference in Young's modulus between the different strata in juxtaposition during unloading cannot, on its own, explain the higher stresses in the anorthosite.

It is recommended that further stress measurements be made in potholes at a variety of depths below surface and across the Bushveld Complex. A better understanding of the stress conditions in potholes could lead to more appropriate support design and avoidance of potential rockbursts in these structures. The reason for the existence of characteristic geological discontinuities around the periphery of potholes should also be investigated.

\section{Acknowledgements}

The CSIR and PlatMine are acknowledged for facilitating the success of the original research work described in this paper.

\section{References}

Ballhaus, C.G. 1988. Potholes of the Merensky Reef at Brakspruit Shaft, Rustenburg Platinum Mines: Primary disturbances in the magmatic stratigraphy. Economic Geology, vol. 83. p. 1140-1158.

CARr, H.W., Groves, D.I., and CAWTHoRne, R.G. 1994. The Importance of synmagmatic deformation in the formation of Merensky Reef potholes in the Bushveld Complex. Economic Geology, vol. 89. p. 1398-1410.

CoETzer, S.J. 1999. Measurement of rock stress at a mine. Consultancy report no. 99-0299.

CoEtzer, S.J. 2005. Personal communication.
CURRAN, J.H. and CoRKum, B.T. 1988. EXAMINE 2D Version 3.1 Users Manual: a 2D boundary element program for calculating stresses around underground excavation in rock, Data Visualization Laboratory, Department of Civil Engineering, University of Toronto.

COMRO. 1981. MINSIM-D user's manual. Chamber of Mines of South Africa, Johannesburg.

ItAsca Consulting Group, Inc. 2017. FLAC3D - Fast Lagrangian Analysis of Continua in Three-Dimensions, Ver. 6.0. Minneapolis: MN.

JageR, A.J. and RYDER, J.A. 1999. A Handbook on Rock Engineering Practice for Tabular Hard Rock Mines, Safety in Mines Research Advisory Committee (SIMRAC), Braamfontein, South Africa. $19 \mathrm{pp}$.

KRUGER, F.J. 2005. Filling the Bushveld Complex magma chamber: Llateral expansion, roof and floor interaction, magmatic unconformities, and the formation of gian chromitite, PGE and Ti-V-magnetitite deposits. Mineralium Deposita, vol. 40 , no. 5. pp.451-472.

LeEman, E.R. and Hayes, D.J. 1966. A technique for determining the complete state of stress in rock using a single borehole. Proceedings of the. 1st Congress. of the International Society of Rock Mechanics, Lisbon. vol. 2. pp. 17-24.

MAP3D. 2013. www.map3D.com.

RYDER, J.A., WATSON, B.P., and KATAKA, M.O. 2005. Estimation of UG2 and Merensky Reef pillar strengths through back-analyses. PlatMine project report, CSIR, Division of Miningtek, Johannesburg.

Sellers, E.J., Coetzer, S.J., and Kamstra, R. 2002. Understanding and determining the variability of the primitive stress environment Appendix A. https://www.mhsc. org.za/ [accessed: 27 September 2018].

Urcan, H., Grodner, M., Watson, B., Lamos, R.A., Roberts, M.K.C., Stewart, R., Souelch, A.P., Le Grange, R., and XABA, D. 2003. Investigate the rock mechanics aspects of potholes in the platinum mines, their contribution to poor ground conditions, and if proactive identification is possible, SIMRAC project GAP 846. Safety in Mines Research Advisory Committee (SIMRAC), Braamfontein, South Africa.

VAN HEERDEN W.L. 1983. Stress-strain relations applicable to overcoring techniques in transversely isotropic rocks. International Journal of Rock Mechanics and Mining Sciences \& Geomechanical Abstracts, vol. 20, no. 6. pp 277-282.

WATSON, B.P. 2004. Report on the workshop examining the loading and unloading history of the Bushveld. Internal report, CSIR, Division of Miningtek, Johannesburg.

Watson, B.P., KuijPers, J.S., Henry, G., Palmer, C.E., and Ryder, J.A. 2009. Nonlinear rock behaviour and its implications on deeper level platinum mining. Journal of the Southern African Institute of Mining and Metallurgy, vol. 108, no. 1. pp 5-13.

Watson, B.P., RobeRTS, M.K.C., Jager, A.J., Naidoo, K., Handley, R., Milev, A.M., RoBerTS, D.P., Sellers, E.J., and Kanagalingam, Y. 2005. Understanding the mechanical properties of the anorthosite suite of rocks. PlatMine project report, CSIR, Division of Miningtek, Johannesburg.

Watson, B.P., Sellers, E.J., Kuijpers, J.S., Grave, D.M.H., Roberts, M.K.C., and COETZER S.J. 2006. Alternative cost effective ways of determining the state of stress in mines. PlatMine project report, CSIR, Division of Miningtek, Johannesburg. 